\title{
Advances in mechanical ventilation
}

I $\mathrm{N}$ the last decade there have been tremendous advances in the technology related to mechanical ventilation as well as in our knowledge of the pathophysiology of acute lung injury. As a result, our approach to ventilation has changed. These changes, their impact on lung injury and patient survival, and some promising new approaches, both simple and complex will be discussed in this review.

\section{Ventilator induced lung injury}

In recent years, a growing body of evidence has delineated the potential role of mechanical ventilation in aggravating or inducing lung injury (VILI). Guidelines for mechanical ventilation have changed dramatically, particularly in the patient with ARDS, where a Lung Protective Ventilation Strategy (LPVS) is now commonly employed. ${ }^{1}$ Several excellent reviews ${ }^{2-5}$ have recently addressed this topic, some pertinent highlights follow.

Animal data have shown that lungs exposed to high airway pressures develop a form of injury (barotrauma) virtually indistinguishable from that of ARDS. ${ }^{6}$ However, high airway pressures are not the only contributing factor in VILI. There is a convincing body of experimental evidence which shows that overdistension of normal lung creates a similar injury (volutrauma) ${ }^{7,8}$ Animal lungs exposed to high pressures but low volumes do not develop the same degree of injury as those exposed to high volumes with low pressures. Overdistension and lung injury are thought to occur when the transpulmonary pressure (peak alveolar pressure minus pleural pressure) exceeds $\mathbf{3 5}$ $\mathrm{cm} \mathrm{H}_{2} \mathrm{O}$ (clinically, the plateau pressure, Pplat, the pressure obtained during an end inspiratory occlusion, is used to reflect the transpulmonary pressure). Hence recent recommendations are to limit $\mathrm{V}_{\mathrm{T}}\left(5-7 \mathrm{ml} \mathrm{kg}^{-1}\right)$ to maintain Pplat $<35 \mathrm{~cm} \mathrm{H}_{2}$ O. ${ }^{1}$

Chest X-rays of patients with ARDS frequently suggest a diffuse and uniform process. However, CT scans show that the lung injury is predominantly found in the dependent lung zones (dorsally located in the supine patient). ${ }^{9}$ Non-ventilated areas contain a mixture of recruitable (potentially ventilated) alveoli and areas of consolidated non-recruitable lung. The amount of normal or ventilated lung is markedly reduced, occupying as little as $20 \%$ of the lung volume, and is located ventrally. Tidal volume $\left(\mathrm{V}_{\mathrm{T}}\right)$ is preferentially directed to the more compliant, ventral areas of lung. $A$ large $V_{T}(>10$ $\mathrm{ml} \cdot \mathrm{kg}^{-1}$ ) would, therefore, create over-distension in what is functionally a "baby lung." 10

If an adequate end-expiratory lung volume is not maintained, airways will collapse, and with each breath there will be cyclic opening and closing of small airways. This is felt to generate shear forces and subsequent lung injury. Animal studies have shown that VILI can be reduced with the application of PEEP, ${ }^{11,12}$ presumably by decreasing airway closure. Therefore, PEEP is not only applied to recruit alveoli, increase FRC, and decrease shunt, but also to prevent VILI. It is not clear whether overdistension or airway closure is more responsible for lung injury.

Using a Pplat $<35 \mathrm{~cm} \mathrm{H} \mathrm{H}_{2} \mathrm{O}$ is arbitrary, and in many circumstances it may still result in overdistension. Conversely, if chest wall compliance is reduced, the lungs may be underdistended at this pressure. It has been suggested that appropriate levels of PEEP and $V_{T}$ can be determined by observing the static pressure-volume (P-V) curve $^{13}$ (Figure 1 ). A change in the slope (upper inflexion point) at the upper end of the inspiratory limb of the P-V curve indicates overdistension; $\mathrm{V}_{\mathrm{T}}$ or PEEP should be decreased accordingly. The lower inflexion point (LIP, Pflex) on the curve indicates an improvement in compliance associated with small airway recruitment. Whether this point actually represents small airway recruitment or alveolar recruitment or neither is a matter of some debate. ${ }^{14}$ Regardless, animal data demonstrates that applying a level of PEEP less than Pflex exacerbates lung injury, and levels of PEEP > Pflex to "keep lungs open" prevents lung injury. ${ }^{11,12}$ Increasing PEEP levels to recruit atelectatic alveoli may necessitate a reduction in $V_{T}$ to prevent overdistension in more compliant areas. As lung zones differ dramatically in compliances, it would seem impossible to find a perfect $V_{T}$ and PEEP level that keeps dorsal airspaces open without overdistending others. It should be noted that the dynamic $P-V$ curve displayed on many ventilators may not be adequate for PEEP titration.

From the Department of Anaesthesia, Ottawa Civic Hospital, 1053 Carling Avenue, Ottawa, Ontario KIY 4E9 Canada. 


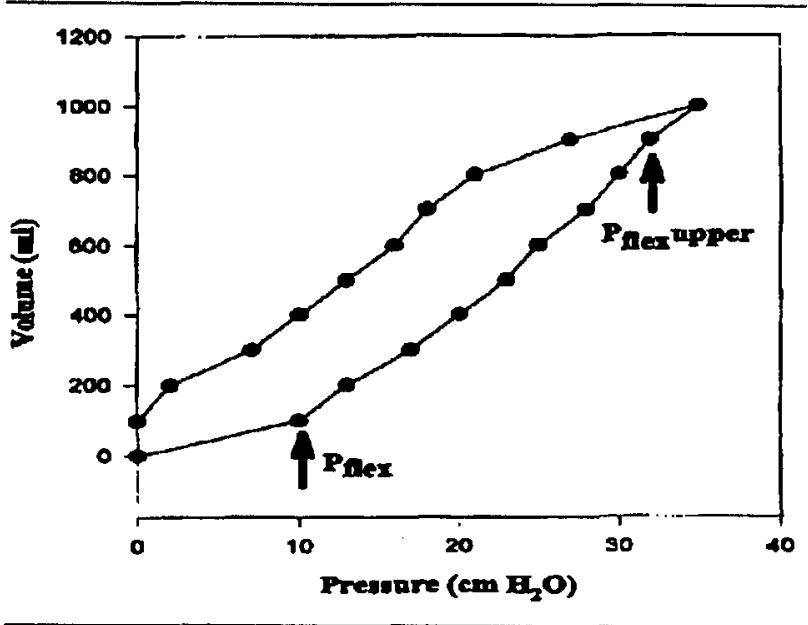

FIGURE Typical static pressure-volume curve of a patient with acute respiratory distress syndrome, which demonstrates pertinent points to the prevention of ventilator-induced lung injury. The inflection point $\left(\mathrm{P}_{\mathrm{flex}}\right)$ or the critical opening pressure of the lungs in this example is at approximately $10 \mathrm{~cm} \mathrm{H_{2 }} 0$. The upper inflection point ( $\mathrm{P}_{\text {fex }}$ upper) where maximum distension of normal lung tissue occurs is slightly greater than $30 \mathrm{~cm} \mathrm{H} \mathrm{H}_{2} \mathrm{O}$. Based on current concepts of lung protective ventilation strategies, the end-expiratory pressure should be above $P_{f l e x}$ and the transpulmonary pressure below $P_{\text {ficx }}$ upper

Reproduced with permission from Stewart TE, Can Respir J 1996; 6: 403-8.

Obtaining a static P-V curve requires some effort, as well as patient paralysis, and inflections points are not always found. Titration of PEEP should also be based on changes in oxygenation and cardiac output.

\section{Permissive hypercapnia/tracheal gas insufflation}

The use of these lung protective strategies frequently results in hypercarbia. Although once feared, studies have shown hypercarbia is generally well tolerated when slowly induced (with certain caveats) ${ }^{15}$ The $\mathrm{PaCO}_{2}$ commonly rises to the $50-80 \mathrm{mmHg}$ range (there are reports of patients tolerating $\mathrm{PaCO}_{2}>100$ $\mathrm{mmHg}$ ). Metabolic compensation occurs over a few days usually resulting in $\mathrm{pH}>7.25$. Acute hypercarbia causes intracellular acidosis, sympathetic activation, cardiovascular and neurological dysfunction, raised ICP, and muscular weakness. Those patients with raised ICP, haemodynamic instability, or who are unable to compensate metabolically may not be ideal candidates for permissive hypercapnia.

If hypercarbia is poorly tolerated or contraindicated, $\mathrm{CO}_{2}$ elimination may be enhanced by tracheal gas insufflation (TGI) ${ }^{16}$ In this technique, fresh gas flow (2-10 $1 \cdot \mathrm{min}^{-1}$ ) is introduced via a catheter positioned near the carina. The fresh gas dilutes anatomical dead space and enhances $\mathrm{CO}_{2}$ removal. Gas flow can be delivered throughout the respiratory cycle or just during expiration. Additional gas flow during inspiration may add to the volume delivered by the ventilator, leading to hyperinflation, auto-PEEP and exceeding the set pressure limits. Mean alveolar pressures and end expiratory lung volumes may rise, even with tracheal gas flow limited to expiration. Several other issues need to be clarified before TGI finds widespread use, including problems with humidification, secretion retention, mucosal injury and safety features in the event of ETT obstruction.

Outcomes in lung protective ventilation strategies Several studies and widespread clinical practice have shown that lung protective strategies are well tolerated, but do they improve outcome? Hickling et al. in a noncontrolled non-randomised trial showed a decrease in mortality ( $v s$ predicted APACHE mortality) using a pressure and volume limited/permissive hypercapnia mode of ventilation. ${ }^{15}$ There have been two recent prospective randomised trials that have not shown an improvement in mortality. Brochard et al. ${ }^{17}$ randomised 108 patients either to a standard ventilation group (with $\mathrm{V}_{\mathrm{T}}>10 \mathrm{ml} \cdot \mathrm{kg}^{-1}$, peak pressure $<60 \mathrm{~cm} \mathrm{H}_{2} \mathrm{O}$, and normal $\mathrm{PaCO}_{2}$ ), or to a limited pressure group (Pplat of $25 \mathrm{~cm} \mathrm{H} \mathrm{H}_{2} \mathrm{O}$ ). There was no difference in mortality $(48 \%$ ps $41 \%)$ or secondary organ failure. Stewart et al. ${ }^{18}$ randomised 112 patients to either a pressure limited approach (PIP $<30 \mathrm{~cm} \mathrm{H} 20, V_{\mathrm{T}}<8 \mathrm{ml} \cdot \mathrm{kg}^{-1}$ ) or a control group $\left(\mathrm{V}_{\mathrm{T}} \mathrm{l0}-15 \mathrm{ml} \cdot \mathrm{kg}^{-1}, \mathrm{PIP}<50 \mathrm{~cm} \mathrm{H}_{2} 0\right)$. Once again, no difference in mortality $(48 \%$ ps $46 \%)$ was found. In another randomised trial which focused on end-expiratory lung volumes as well as peak pressures, Amato et al. ${ }^{19}$ demonstrated an improvement in mortality. His group used pressure and volume limitation combined with PEEP levels > Pflex. Further trials will, hopefully, clarify the optimal approach to pressure limitation, volume limitation, and appropriate PEEP levels, and their impact on morbidity and mortality.

\section{Ventilation modes}

A variety of different modes of mechanical ventilation have been used to manage the patient with ARDS. Recently, attention has been paid to various forms of pressure controlled ventilation and inverse ratio ventilation (IRV). There is no overwhelming evidence to suggest any one mode of ventilation is clearly superior to another. ${ }^{20}$ The major advantage to pressure targeted ventilation is that peak and alveolar pressures are kept constant (less barotrauma). On the down side is the fact that $V_{T}$ changes as lung mechanics change. Volume targeted ventilation guarantees a constant $\mathrm{V}_{\mathrm{T}}$ but invokes 
the risk of barotrauma. Changes in patient demand are less likely to be satisfied with volume controlled ventilation, leading to increased patient effort and distress. Extension of inspiratory times has been used to improve oxygenation (IRV). Improved oxygenation is a result of an increase in mean airway pressure (without an increase in peak pressures). If mean airway pressures and total PEEP (external plus intrinsic) are kept constant, there is no difference in oxygenation between normal and inverse ratio ventilation..$^{21}$

Two new promising modes of ventilation that allow some degree of spontaneous breathing are, proportional assist ventilation (PAV), and airway pressure release ventilation (APRV). With PAV, the pressure delivered from the ventilator increases in proportion to the patients effort, a form of positive feedback. This may provide more comfort and better patient-ventilator interaction. APRV allows spontaneous breathing on a preset level of CPAP which is interrupted by brief releases of pressure for further expiration. This allows minimal deviation from an "optimal" lung volume and may limit risks of baro or volutrauma. A detailed examination of these techniques is beyond the scope of this article, and as yet neither mode is in widespread clinical use.

\section{Partial liquid ventilation}

Perflurochemicals (PFCs) are enviromentally innocuous liquids that dissolve large volumes of oxygen and carbon dioxide. Partial Liquid Ventilation (PLV) is a technique where PFCs are instilled into the lungs via the endotracheal tube in a sufficient volume to fill FRC. The liquid preferentially re-opens and distends dependant alveoli, allowing oxygen exchange. As well, blood flow is redistributed toward nondependant and better ventilated areas, thereby decreasing shunt. PFC's are very dense, hence airway secretions and alveolar exudates tend to float upon the liquid, this may help clear alveoli. Initial reports of PLV in adults and infants are promising, however there is still much to learn. ${ }^{5}$

\section{Nitric oxide}

Nitric oxide (NO) causes vasodilatation. When inhaled, it has the potential to vasodilate pulmonary arteries and improve perfusion to the areas that are best ventilated. In patients that respond to NO, shunt decreases, oxygenation improves, and pulmonary hypertension may be reduced. Although NO is now used in many ICUs, many questions remain: What is the best method of delivery?; What toxicities are there?; Does it improve morbidity and mortality?; Which patients will respond? Ongoing trials may clarify some of these issues. A discussion of these questions is beyond the scope of this article.

\section{Prone positioning}

In 1974, Froese and Bryan $^{22}$ demonstrated that mechanical ventilation aggravates the loss of dependent lung volume. Bryan subsequently postulated that the only feasible way of expanding dependent portions of the lung would be by placing the patient prone. ${ }^{23} \mathrm{He}$ also stated that PEEP would be ineffective in relieving dependent collapse as PEEP would be preferentially directed to non dependent areas.

CT scans clearly demonstrate the dependent nature of lung densities in ARDS, and the relative inefficiency of PEEP in reducing these densities, as predicted PEEP is preferentially directed to the non dependent more compliant regions. Placing patients prone results in a redistribution of lung densities to the previous ventral lung zones, with rapid improvement in the dorsal areas. ${ }^{24}$ Clinical studies show a significant improvement in oxygenation in a large number $(>50 \%)$ of patients when turned prone. ${ }^{25-27}$ The improvement in oxygenation is of a similar magnitude to that induced by nitric oxide, and frequently allows adjustments in $\mathrm{FIO}_{2}$, PEEP, and ventilator settings. The improvement in oxygenation usually occurs rapidly (minutes) after the first turning, although there are reports of "late responders." The improvements in oxygenation may be diminished upon resumption of the supine position, however several reports show long lasting effects. Repeated episodes of "proning" may have a cumulative effect. The optimal duration of prone positioning is not known, reports vary from hours to days; duration should be titrated to individual responses. Intervals in the supine position are required for nursing care, medical evaluation and performance of medical procedures. The majority of studies show few complications, these include minor mucosal and skin injuries, dependent oedema, and inadvertent removal of vascular lines or endotracheal tubes. Most patients tolerate the position change without significant haemodynamic alterations. Contraindications to prone positioning may include raised ICP, unstable spinal or pelvic fractures, and intraabdominal pathology.

Why does the prone position improve oxygenation? In the supine position there is a steep vertical gradient of pleural pressure which promotes airway closure in dependent, oedematous areas. Gravity still influences pleural pressures in the prone position but its effects are modified by different positional forces of the heart, rib cage, diaphragm, abdomen, and mediastinal structures. The result is a more uniform distribution of pleural pressures which allows a more homogeneous distribution of ventilation. ${ }^{28}$ As perfusion is minimally affected in the prone position, improved ventilation in dorsal areas will improve $V / Q$ ratios and 
reduce shunt. If lung injury is limited by decreasing tidal volumes and by preventing cyclic opening and closing of alveoli, then the prone position may not only improve oxygenation but prevent further injury. Indeed, animal studies show that compared with the supine position, prone positioning prevents lung injury induced by overdistension of normal lungs ${ }^{29}$ and also diminishes the degree of histologic abnormalities in a animal model of acute lung injury. ${ }^{30}$ Improved drainage of secretions from dependent lung zones may also contribute to improved oxygenation.

As a result of the many case reports and case series showing an improvement in oxygenation, prone positioning is now in widespread use. A recent case series ${ }^{27}$ has shown improved mortality (compared with APACHE prediction), but there are as yet no prospective randomised controlled trials showing improvement in morbidity and mortality. There are no firm guidelines as when the patient should be "flipped"; the decision is usually based on oxygenation criteria. If the prone position is "protective" then an argument could be made for early or even prophylactic turning in those at high risk for ARDS.

There are many reasons why prone positioning should be considered a first line therapy: it is effective, it may prevent VILI, it is easy to perform, it is safe, there are few contraindications, it is not technically demanding, it can be done anywhere, and it is not expensive.

\section{Noninvasive ventilation}

The term noninvasive ventilation (NIV) refers to a variety of ventilation techniques that do not use an endotracheal tube. There are several potential advantages of NIV: avoiding complications of intubation (including nosocomial pneumonia), less sedative requirements, and preservation of speech, swallowing, and airway defence mechanisms. It has been available for decades, initially in the form of negative pressure ventilation (iron lung), and more recently positive pressure delivered via a mask. Traditionally, NIV has been used in certain chronic respiratory conditions such as sleep apnoea, neuromuscular weakness, and COPD. Recently, considerable attention has been focused on the use of NIV in acute respiratory failure (ARF). Although numerous modes of mechanical ventilation have been successfully delivered via a mask, considerable work has focused on CPAP with pressure support (PS). Pressure support allows the patient control over inspiratory and expiratory times, and compensates for leaks. CPAP refers to continuous positive pressure alone whereas intermittent positive pressure (with or without CPAP) is called noninvasive positive pressure ventilation (NPPV).

The majority of trials have evaluated the effect of NIV on ARF secondary to an exacerbation of COPD.
Patients with premature airway closure develop dynamic hyperinflation and intrinsic PEEP (PEEPi). Inspiratory muscles must generate enough negative pressure to overcome PEEPi before inspiratory flow starts. Mask CPAP counterbalances the inspiratory threshold load induced by PEEPi, thereby decreasing inspiratory muscle work. NPPV increases minute ventilation, decreases inspiratory work, and improves gas exchange. The combination of CPAP and NPPV is superior to either alone. ${ }^{31}$ Several prospective randomised studies have shown improvement in various endpoints including: a reduction in the need for tracheal intubation, shorter hospital stays and a decrease in mortality. ${ }^{32-34}$ There are numerous criticisms of the individual trials: patients were highly selected, some control patients that died were never intubated, and a variety of different techniques were used to administer NPPV. A recent meta-analysis has shown that the addition of NPPV to standard treatment of patients with ARF secondary to COPD decreases the likelihood of intubation and also decreases mortality. ${ }^{35}$ As there is lack of data, a statement of similar strength cannot be made for ARF due to causes other than COPD. ${ }^{36}$ Uncontrolled trials have suggested a benefit in acute severe asthma but further investigations are necessary. Studies have shown the benefit of NPPV in improving gas exchange, haemodynamics, and respiratory variables in patients with cardiogenic pulmonary oedema, presumably by reducing preload and afterload. NPPV has become first line therapy for patients with cystic fibrosis requiring ventilatory support while awaiting lung transplantation. ${ }^{36}$ It has been used successfully in postoperative atelectasis and respiratory failure.

Non-invasive ventilation can be administered with a standard ventilator or via a specialised device that delivers inspiratory and expiratory pressures. Patients should be alert and co-operative (with the exception of $\mathrm{CO}_{2}$ narcosis), have no need for airway protection, be haemodynamically stable, and be able to be fitted with a mask. Full or nasal masks may be used. Mouth breathing may decrease the effectiveness of a nasal mask. However, nasal masks are less claustrophobic, allow for expectoration and oral intake without mask removal. Complications are infrequent and include skin necrosis, gastric distention, eye irritation and mask discomfort. For details of how to institute NIV, practical tips, and nursing implications, the reader is referred to two excellent reviews. ${ }^{36,37}$

\section{Conclusion}

Although a considerable amount of experimental data exists, preliminary clinical studies of pressure and volume limited ventilation have not established its role and benefit in patients with acute lung injury. Indeed, there 
are no controlled studies that prove any form of mechanical ventilation is superior to another in ARDS. Prone positioning should be considered early in the course of ARDS, not only for treatment of hypoxia but also for its potential lung-protective effects. Tracheal gas insufflation shows promise in alleviating troublesome hypercarbia associated with pressure and volume limited ventilation. For appropriate patients, the obvious and more insidious complications associated with tracheal intubation may be avoided with the use of NIV. NIV has clearly found a important role in the management of ARF secondary to COPD, and has promise in the management in many other forms of ARF.

\section{Acknowledgement}

The author would like to thank Karen Kinney for her invaluable secretarial assistance and numerous colleagues for their wise insights.

\section{References}

1 Slutsky AS. Mechanical ventilation. Chest 1993; 104: 1833-59.

2 Lessard MR. New concepts in mechanical ventilation for ARDS. Can J Anaesth 1996; 43: R50-4.

3 Stewart TE. Establishing an approach to mechanical ventilation. Can Respir J 1996; 3: 403-8.

4 Burchardi $H$. New strategies in mechanical ventilation for acute lung injury. Eur Respir J 1996; 9: 1063-72.

5 Marini JJ. Evolving concepts in the ventilatory management of acute respiratory distress syndrome. Clinics in Chest Medicine 1996; 17: 555-75.

6 Dreyfuss $D$, Basset $G$, Soler $P$, Saumon G. Intermittent positive-pressure hyperinflation with high inflation pressures produces pulmonary microvascular injury in rats. Am Rev Respir Dis 1985; 132: 880-4.

7 Dreyfuss D, Soler $P$, Basset $G$, Saumon G. High inflation pressure pulmonary edema. Respective effects to high airway pressure, high tidal volume and positive endexpiratory pressure. Am Rev Respir Dis 1988; 137 : 1159-64.

8 Cilley RE, Wang JY, Coran $A G$. Lung injury produced by moderate overinflation in rats. J Ped Surg 1993; 28: 488-95.

9 Maunder RJ, Shuman WP, McHugh JW, Marglin SI, Butler $J$. Preservation of normal lung regions in the adult respiratory distress syndrome. JAMA 1986; 255: 2463-5.

10 Gattinoni $L$, Pesenti $A$, Bombino $M$, et al. Relationships between lung computed tomographic density, gas exchange, and PEEP in acute respiratory failure. Anesthesiology 1988; 69: 824-32.
11 Muscedere JG, Mullen JBM, Gan K, Slutsky AS. Tidal ventilation at low airway pressures can augment lung injury. Am J Repir Crit Care Med 1994; 149: 1327-34.

12 Sandhar BK, Niblett DJ, Argiras EP, et al. Effects of positive end expiatory pressure on hyaline membrane formation in a rabbit model of the neonatal respiratory distress syndrome. Intensive Care Med 1988; 14: 538-46.

13 Roupie E, Dambrosio $M$, Servillo $G$, et al. Titration of tidal volume and induced hypercapnia in acute respiratory distress syndrome. Am J Respir Crit Care Med 1995; 152: 121-8.

14 Mergoni $M$, Volpi $A$, Rossi $A$. Inflection point and alveolar recruitment in ARDS. In: Vincent JL (Ed.). Update 1997 in Intensive Care and Emergency Medicine. Berlin: Springer-Verlag, 1997: 556-67.

15 Hickling $K G$, Walsh J, Henderson S, Jackson R. Low mortality rate in adult respiratory distress syndrome using low-volume, pressure-limited ventilation with permissive hypercapnia: a prospective study. Crit Care Med 1994; 22: 1568-78.

16 Kalfon $P$, Umamaheswara Rao GS, Gallart $L$, et al. Permissive hypercapnia with and without expiratory washout in patients with severe acute respiratory distress syndrome. Anesthesiology 1997; 87: 6-17.

17 Brochard $L$, Roudot-Thoraval $F$, and the collaborative group on Vt reduction. Tidal volume (Vt) reduction in acute respiratory distress syndrome (ARDS): a multicenter randomized study. Am J Respir Crit Care Med 1997; 155: A5O5.

18 Stewart TE, Meade MO, Granton J, Lapinsky S, Hodder $R$, et al. Pressure and volume limited ventilation strategy (PLVS) in patients at high risk for ARDS-results of a multicenter trial. Am J Respir Crit Care Med 1997; 155: A5O5.

19 Amato MBP, Barbas CSV, Medeiros D, et al. Improved survival in ARDS: beneficial effects of a lung protective strategy. Am J Respir Crit Care Med 1996; 153: A531.

20 Kacmarek RM. Current status of new modes of mechanical ventilation. Can Respir J 1996; 3: 357-60.

21 Lessard $M R$, Guerot $E$, Lorino $H$, Lemaire $F$, Brochard $L$. Effects of pressure-controlled with different I:E ratio versus volume-controlled ventilation on respiratory mechanics, gas exchange, and hemodynamics in parients with Adult Respiratory Distress Syndrome. Anesthesiology 1994; 80: 983-91.

22 Froese $A$, Bryan $A C$. Effects of anesthesia and paralysis on diaphragmatic mechanics in man. Anesthesiology 1974; 41: 242-55.

23 Bryan AC. Comments of a Devil's Advocate. Am Rev Respir Dis 1974: 1 10(Suppl): 143-4.

24 Gattinoni L, Pelosi P, Vitale $G$, et al. Body position changes redistribute lung computed tomographic density in patients with acute respiratory failure. Anesthesiology 1991; 74: 15-23. 
25 Albert $R K$. For every thing (turn...turn...turn...) (Editorial). Am J Respir Crit Care Med 1997; 155: 393-4.

26 Chatte G, Sab J-M, Dubois J-M, Sirodot M, Gaussorgues $P$, Robert $D$. Prone position in mechanically ventilated patients with severe acute respiratory failure. Am J Respir Crit Care Med 1997; 155: 473-8.

27 Stocker R, Neff T, Stein S, Ecknauer E, Trentz O, Russi $E$. Prone positioning and low-volume pressure limited ventilation improve survival in patients with severe ARDS. Chest 1997; 111: 1008-17.

$28 \mathrm{Lamm}$ WJE, Grabam MM, Albert RK. Mechanism by which the prone position improves oxygenation in acute lung injury. Am J Respir Crit Care Med 1994; 150: 184-93.

29 Broccard AF, Shapiro RS, Adams AB, Ravenscraft $S A$, Marini $J$. Effect of body position on lung injury induced by mechanical ventilation in dogs: prone versus supine. Am J Respir Crit Care Med 1995: 151: A551.

30 Broccard AF, Shapiro RS, Schmitz LL, Ravenscraft $S A$, Marini JJ. Influence of prone position on the extent and distribution of lung injury in a high tidal volume oleic acid model of acute respiratory distress syndrome. Crit Care Med 1997; 25: 16-27.

31 Appendini L, Patessio A, Zanaboni S, et al. Physiological effects of positive end-expiratory pressure and mask pressure support during exacerbations of chronic obstructive pulmonary disease. Am J Respir Crit Care Med 1994; 149: 1069-76.

32 Kramer N, Meyer TJ, Meharg J, Cece RD, Hill NS. Randomized, prospective trial of noninvasive positive pressure ventilation in acute respiratory failure. Am J Respir Crit Care Med 1995; 151: 1799-806.

33 Wysocki $M$, Tric L, Wolff $M A$, Millet $H$, Herman $B$. Noninvasive pressure support ventilation in patients with acute respiratory failure. Chest 1995; 107: 761-8.

34 Brochard L, Mancebo J, Wysocki M, et al. Noninvasive ventilation for acute exacerbations of chronic obstructive pulmonary disease. N Eng J Med 1995; 333: 817-22.

35 Keenan SP, Kernerman PD, Cook DJ, Martin C, $M c$ Cormack $D$, Sibbald WJ. Effect of noninvasive positive pressure ventilation on mortality in patients admitted with acute respiratory failure: a meta-analysis. Crit Care Med 1997; 25: 1685-92.

36 Meduri GU. Noninvasive positive-pressure ventilation in patients with acute respiratory failure. Clinics in Chest Medicine 1996; 17: 513-53.

37 Ambrosino $N$. Noninvasive mechanical ventilation in acute respiratory failure. Eur Respir J 1996; 9: 795-807. 


\section{Progrès en ventilation mécanique}



A dernière décennie a été une période fertile quant aux progrès de la technologie associće à la ventilation mécanique, ainsi qu'à nos connaissances ayant trait à la pathophysiologie des insultes pulmonaires aiguës. Cela s'est traduit par une approche différente de la ventilation mécanique.

Cet article révisera donc ces changements, leur impact quant aux lésions pulmonaires et à la survie des patients, de même que certaines nouvelles avenues intéressantes, certaines plus simples, d'autres plus complexes.

\section{Lésions pulmonaires induites par le ventilateur}

Au cours des dernières années, une accumulation de preuves a souligné le rôle potentiel de la ventilation mécanique comme source ou facteur contributif des lésions pulmonaires (LPIV : lésions pulmonaires induites par la ventilation). Les lignes directrices concernant la ventilation mécanique ont beaucoup changé, particulièrement dans les cas de syndrome de détresse respiratoire de l'adulte (SDRA) où l'on emploie plus fréquemment des stratégies de ventilation protectrice (SVP). ${ }^{1}$ Ce sujet a récemment fait l'objet de plusieurs excellentes revues, dont nous avons extrait quelques points importants. ${ }^{2-5}$

Des études animales ont démontré que des poumons normaux, soumis à de hautes pressions des voies aériennes, développent un tableau lésionnel (barotrauma) semblable à celui du SDRA. ${ }^{6}$ Cependant, de hautes pressions au niveau des voies aériennes ne sont pas le seul facteur contribuant aux LPIV. En effet, de nombreuses évidences expérimentales démontrent que l'hyperinflation d'un poumon normal cause des lésions comparables (volutrauma).7,8 Les poumons animaux soumis à de hautes pressions mais à de bas volumes ne développent pas autant d'atteinte que ceux soumis à de basses pressions/hauts volumes. L'hyperinflation et les lésions pulmonaires surviendraient lorsque la pression transpulmonaire (pression de pointe alvéolaire - pression pleurale) dépasse $35 \mathrm{~cm} \mathrm{H}_{2} \mathrm{O}$ (au plan clinique, la pression plateau, $P_{\text {plat }}$ est la pression obtenue par une occlusion en fin d'inspiration et est utilisée comme reflet de la pression transpulmonaire). D'où les recommandations actuelles, dans le SDRA, de limiter le $\mathrm{V}_{\mathrm{T}}$ à $5-7 \mathrm{ml} \cdot \mathrm{kg}^{-1}$ et de maintenir $\mathrm{P}_{\text {plat }}<35 \mathrm{~cm} \mathrm{H}_{2} \mathrm{O}$. ${ }^{1}$

La radiographie pulmonaire dans le SDRA suggère un processus diffus et uniforme. La réalité est toute autre : tel que le démontre la tomodensitométric, les lésions pulmonaires sont surtout retrouvées dans les zones pulmonaires déclives, ${ }^{9}$ i.e., les zones dorsales chez un patient couché. Les zones non-ventilées se divisent en alvéoles recrutables, donc potentiellement ventilables, et en zones consolidées, donc non-recrutables. La quantité de poumon normal ou ventilé est réduite de façon marquée, occupant aussi peu que $20 \%$ du volume pulmonaire total et se retrouve du côté ventral. Le volume courant $\left(\mathrm{V}_{\mathrm{T}}\right)$ est préférentiellement dirigé vers la région ventrale, plus compliante. Un grand $V_{T}$, (de $>10 \mathrm{ml} \cdot \mathrm{kg}^{-1}$ ) aura donc tendance à créer une surdistension dans ce qui est fonctionnellement un "poumon de bébé.»10

Si un volume pulmonaire de fin d'expiration n'est pas maintenu, les voies aériennes se collaberont, et chaque cycle respiratoire sera donc une suite cyclique d'ouverture et de fermeture des petites voies aériennes. Ce phénomène générerait des forces de cisaillement probablement responsables de lésions pulmonaires. Les études animales ont montré que les LPIV peuvent être réduites par l'application de PEEP, ${ }^{11,12}$ possiblement en diminuant la fermeture des voies aériennes. Ainsi, la PEEP est utile pour recruter des alvéoles, augmenter la CRF, diminuer le shunt, mais aussi pour prévenir les LPIV. Néanmoins, il n'est pas clair laquelle de l'hyperinflation ou de la fermeture des voies aériennes est la plus responsable des lésions pulmonaires.

L'utilisation d'une $\mathrm{P}_{\text {plat }}<35 \mathrm{~cm} \mathrm{H} \mathrm{H}_{2} \mathrm{O}$ est arbitraire, et dans de nombreuses circonstances entraîne néanmoins de l'hyperinflation. Inversement, si la compliance thoracique est diminuée, les volumes pulmonaires peuvent être petits à cette même pression. On a suggéré que les niveaux appropriés de PEEP et de $V_{T}$ soient déterminés à partir des courbes pression-volume $(\mathrm{P}-\mathrm{V})$ statiques (Figure). ${ }^{13}$ Un changement dans la pente à la fin de la portion inspiratoire de la courbe P-V (point d'inflexion supérieur) indique une hyperinfiltration; le $\mathrm{V}_{\mathrm{T}}$ ou la PEEP devraient être réduits de façon appropriée; le point d'inflexion inférieur (LIP, $\mathrm{P}_{\text {flax }}$ ) sur la même courbe indique une amélioration de la compliance due au recrutement de petites voies aériennes. $\grave{A}$ savoir si ce point représente du recrutement de petites voies aériennes ou un recrutement alvéolaire, ou aucun des deux, reste sujet de controverse. ${ }^{14}$ Néanmoins, des données animales démontrent que l'application de PEEP $<\mathrm{P}_{\text {flex }}$ augmente les lésions pulmonaires, alors 


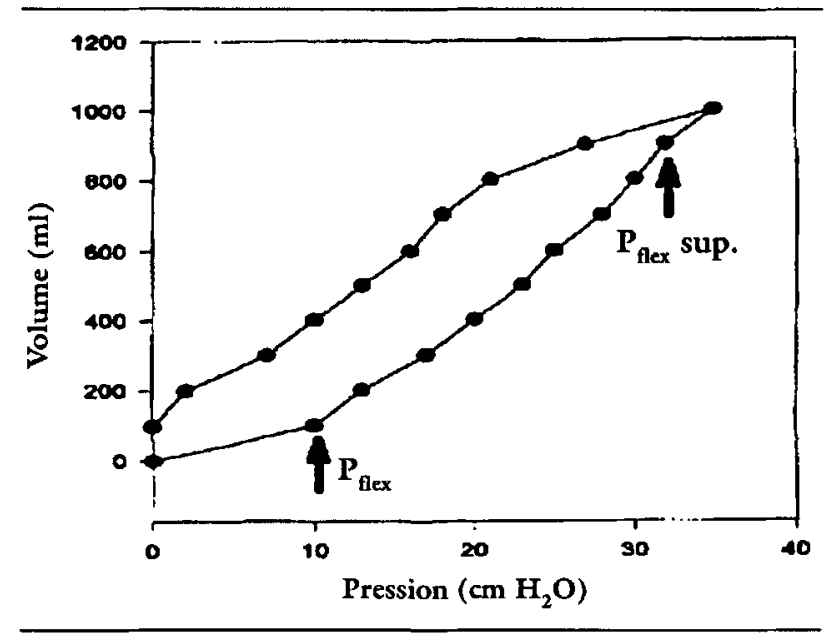

FIGURE Courbe pression-volume statique typique d'un patient avec SDRA démontrant les éléments pertinents à la prévention de lésions pulmonaires secondaires à la ventilation mécanique. Le point d'inflexion $\left(\mathrm{P}_{\mathrm{flex}}\right)$ ou pression critique d'ouverture du poumon est approximativement de $10 \mathrm{~cm} \mathrm{H}_{2} \mathrm{O}$ dans cet exemple. Le point d'inflexion supérieur $\left(\mathrm{P}_{\text {flex upper }}\right)$ où la distension maximale du tissu pulmonaire normal survient se situe à un peu plus de $30 \mathrm{~cm} \mathrm{H}_{2} \mathrm{O}$. Selon les concepts actuels de ventilation protectrice du poumon, la pression de fin d'expiration devrait être au-dessus de $\mathrm{P}_{\text {flex }}$ et la pression transpulmonaire inférieure à $\mathrm{P}_{\mathrm{flcx}}$ upper

Reproduit avec l'autorisation de Stewart TE, Can Resp J 1996; 6: 403-8.

L'auteur desire remercier Karen Kinney pour son précieux support secrétarial de même que de nombreux collègues pour leurs sages conseils.

que des niveaux de PEEP $>\mathrm{P}_{\text {flex }}$ pour «garder le poumon ouvert» (open lung) préviennent les lésions pulmonaires. ${ }^{11,12}$ L'augmentation de PEEP pour recruter des alvéoles atélectasiées peut devoir s'accompagner d'une diminution de $\mathrm{V}_{\mathrm{T}}$ afin de prévenir l'hyperinflation de zones plus compliantes. Étant donné les différences marquées de compliances, il apparaît impossible de trouver un $V_{T}$ et un PEEP parfait, i.e., qui maintiendraient ouvertes les zones plus dorsales sans distendre des segments déjà ouverts. Il est important de noter que les courbes $\mathrm{P}-\mathrm{V}$ dynamiques affichées sur de nombreux ventilateurs ne sont probablement pas adéquates pour cette titration du PEEP. L'obtention d'une courbe statique de P-V demande un certain effort, de même qu'un patient paralysé. De plus, les points d'inflexion ne sont pas toujours trouvés. La titration de la PEEP se doit aussi d'être basée sur les changements au niveau de l'oxygénation et du débit cardiaque.

\section{Hypercapnie permissive/insufflation trachéale}

L'utilisation des stratégies ventilatoires que nous venons de présenter s'accompagnent fréquemment d'hypercarbie. Bien que par le passé on la craignait, les études mon- trent que l'hypercarbie est généralement bien tolérée lorsqu'induite lentement. ${ }^{15} \mathrm{La}^{\mathrm{PaCO}_{2}}$ s'élève souvent à des niveaux de $50-80 \mathrm{mmHg}$ (certains auteurs ont rapporté des patients ayant toléré des $\mathrm{PaCO}_{2}>100$ ). $\mathrm{La}$ compensation métabolique s'établit en quelques jours pour obtenir un $\mathrm{pH}>7,25$. L'hypercarbie aiguë cause une acidose intracellulaire, une activation sympathique, des dysfonctions cardiovasculaire et neurologique, une hausse de la PIC et une faiblesse musculaire. Les patients ayant une PIC élevée, de l'instabilité hémodynamique, ou incapables de compenser métaboliquement ne seraient pas de bons candidats pour l'hypercapnie permissive.

Si l'hypercarbie est mal tolérée ou contre-indiquée, l'élimination du $\mathrm{CO}_{2}$ peut être accrue par l'insufflation de gaz intrathécal (IGT).${ }^{16}$ Cette technique consiste à introduire un flot de gaz frais $(2-10 \mathrm{l} / \mathrm{min})$ via un cathéter placé à proximité de la carène. Le flot de gaz dilue l'espace mort anatomique et ainsi améliore l'élimination du $\mathrm{CO}_{2}$. Le flot de gaz peut être donné durant le cycle respiratoire ou seulement durant l'expiration. Le flot de gaz additionnel donné durant l'inspiration peut s'ajouter au volume généré par le respirateur, entraînant une hyperinflation, de l'auto PEEP et dépassant les limites de pression établies. Les pressions alvéolaires moyennes et les volumes pulmonaires en fin d'expiration peuvent augmenter, même si le flot de gaz trachéal est limité à l'expiration. De nombreux points restent à préciser avant de généraliser l'utilisation de cette méthode, notamment des problèmes concernant l'humidification, la rétention de sécrétions, les blessures aux muqueuses et les mesures de sécurité dans l'éventualité d'une obstruction du tube endotrachéal.

\section{Devenir associé aux stratégies de ventilation protectrice}

Plusieurs études et la pratique clinique ont montré que les stratégies de ventilation protectrice sont bien tolérées. Mais améliorent-elles le devenir? Hickling et al., dans une étude non-contrôlée, non randomisée, ont montré une diminution de la mortalité (vs mortalité prédite par le score d'Apache) lors de l'utilisation d'une ventilation limitant la pression et le volume associée à une hypercapnie permissive. ${ }^{15}$ Deux récentes études prospectives randomisées n'ont pas montré de diminution de la mortalité. Brochard et al. ${ }^{17}$ ont randomisé 108 patients en 2 groupes; soit un groupe de ventilation «standard» $\left(\mathrm{V}_{\mathrm{T}}>10 \mathrm{ml} \cdot \mathrm{kg}^{-1}, \mathrm{P}_{\text {pointe }}<60 \mathrm{~cm} \mathrm{H} \mathrm{H}_{2} \mathrm{O}, \mathrm{PCO}_{2}\right.$ normale) ou un groupe avec ventilation «pressionlimitée» ( $\mathrm{P}_{\text {plat }} 25 \mathrm{~cm} \mathrm{H} \mathrm{H}_{2} \mathrm{O}$ ). Aucune différence dans la mortalité ( $48 \%$ vs $41 \%)$ ou dans l'insuffisance organique secondaire n'a été montrée. Stewart et al. ${ }^{18}$ ont ran- 
domisé 112 patients soit à un groupe "pression-limitée» ( $\mathrm{PIP}<30 \mathrm{~cm} \mathrm{H} \mathrm{H}_{2} \mathrm{O}, \mathrm{V}_{\mathrm{T}}<8 \mathrm{ml} \cdot \mathrm{kg}^{-1}$ ) soit à un groupe contrôle $\left(\mathrm{V}_{\mathrm{T}} 10-15 \mathrm{ml} \cdot \mathrm{kg}^{-1}, \mathrm{PIP}<50 \mathrm{~cm} \mathrm{H}_{2} \mathrm{O}\right)$. Là encore, aucune différence dans la mortalité ( $48 \%$ vs $46 \%$ ) n'a été trouvée. Dans une autre étude randomisée portant sur les volumes pulmonaires en fin d'expiration de même que sur les pressions de pointe, Amato $e t$ al. ${ }^{19}$ ont démontré une amélioration de la mortalité. Ce groupe utilisait des volumes et des pressions limités ainsi que des niveaux de PEEP $>\mathrm{P}_{\text {flex }}$. D'autres études seront nécessaires pour déterminer l'approche optimale quant aux limitations de pression et de volume, aux niveaux appropriés de PEEP, ainsi que leurs impacts sur la morbidité et la mortalité.

\section{Modes de ventilation}

De nombreux modes de ventilation ont été utilisés pour traiter les patients avec SDRA. Récemment, beaucoup d'emphase a été mise sur les diverses formes de ventilation à pression contrôléc et en ratio inversé (VRI). Cependant, il y a peu d'évidence pour suggérer qu'un mode de ventilation soit supérieur. ${ }^{20}$ L'avantage majeur de la ventilation à pression contrôlée est que les pressions de pointe et alvéolaire sont gardées constantes (moins de barotrauma). Le désavantage est que le $\mathrm{V}_{\mathrm{T}}$ change lorsque la mécanique pulmonaire change. La ventilation à volume contrôlé garantit un $\mathrm{V}_{\mathrm{T}}$ constant mais implique la possibilité de barotrauma. De plus, des changements dans la demande du patient sont moins bien satisfaites lorsqu'il est ventilé en volume contrôlé, ce qui conduit à plus d'effort du patient et à une certaine détresse. L'augmentation des temps inspiratoires (VRI) a été utilisée pour améliorer l'oxygénation. Cette amélioration résulte d'une augmentation des pressions moyennes des voies aériennes, sans augmentation des pressions de pointe. Cependant, si les pressions moyennes des voies aériennes et la PEEP totale (extrinsèque et intrinsèque) sont gardées constantes, il n'y a pas de différence dans l'oxygénation entre la ventilation conventionnelle et celle à ratio inversé. ${ }^{21}$

Il existe deux nouveaux modes de ventilation prometteurs, qui permettent un certain degré de ventilation spontanée : la ventilation assistée proportionnelle (proportional assist ventilation) et la ventilation à relâchement de pression (airway pressure release ventilation). Dans le premier mode, la pression donnée par le respirateur augmente proportionnellement à l'effort du patient, sorte de feedback positif, ce qui permettrait plus de confort et une meilleure interaction patientventilateur. Dans le second mode, le patient respire spontanément à un niveau de CPAP déterminé, qui est interrompu par de brefs relâchements de la pression afin de favoriser une expiration plus complète ceci afin de maintenir un volume pulmonaire «optimal» et ainsi minimiser les risques de baro ou de volutrauma. Un examen détaillé de ces techniques dépasse la portée de cet article, d'autant plus que ces deux modes ne sont pas encore utilisés de façon routinière.

\section{Ventilation liquide partielle}

Les perfluorocarbones (PFC) sont des liquides inertes capables de dissoudre d'importantes quantités d'oxygène et de $\mathrm{CO}_{2}$. La ventilation liquide partielle (VLP) est une technique où des PFC sont instillés, via le tube endotrachéal, dans les poumons jusqu'à saturer la CRF. Le liquide ouvre et distend préférentiellement les alvéoles dépendantes, permettant ainsi l'oxygénation. De plus, le flot sanguin est redistribué en partie vers des zones nondépendantes et mieux ventilées, diminuant ainsi le shunt. Finalement, comme les PRF sont denses, les sécrétions et exsudats alvéolaires ont ainsi tendance à flotter à la surface du liquide, facilitant le nettoyage des alvéoles. Les premiers rapports de l'urilisation de la VLP chez des adultes et des enfants sont prometteurs, mais beaucoup reste à apprendre.

\section{Oxyde nitrique (NO)}

Le No cause une vasodilatation. Lorsqu'inhalé, il a le potentiel de vasodilater les vaisseaux pulmonaires et ainsi d'améliorer la perfusion dans les zones les mieux ventilées. Chez les patients qui répondent au NO, le shunt décroît, l'oxygénation s'améliore et l'hypertension pulmonaire peut diminuer. Bien qu'utilisé dans de nombreux soins intensifs, on se pose plusieurs questions : quel est le meilleur moyen de l'administrer? Quelles en sont les toxicités? Améliore-t-il la morbidité et la mortalité? Quels patients y répondront? Plusieurs études actuellement en cours tentent de répondre à ces questions. La discussion de ces questions dépasse la portée de cet article.

\section{Décubitus ventral}

En 1974, Froese et Bryan 22 ont démontré que la perte de volume pulmonaire dans les zones déclives était aggravée par la ventilation mécanique. Bryan émit par la suite le postulat suivant : la seule façon d'ouvrir les zones dépendantes est de placer le patient en décubitus ventral. ${ }^{23}$ Il statua aussi que la PEEP serait inefficace pour rouvrir les zones dépendantes atélectasiées car la PEEP s'appliquerait préférentiellement aux zones nondépendantes.

L'étude par tomodensitométrie montre clairement la position déclive des opacités pulmonaires dans le SDRA, ainsi que le peu d'efficacité de la PEEP à diminuer ces opacités, par son action préférentielle à dilater les zones non-dépendantes, plus compliantes. 
Par le positionnement des patients en décubitus ventral, les opacités se redistribuent rapidement vers les zones ventrales, améliorant rapidement les zones dorsales. ${ }^{24}$ Les études cliniques montrent une amélioration significative chez de nombreux patients $(>50 \%)$ lorsque ainsi positionnés. ${ }^{25-27}$ L'amélioration de l'oxygénation est similaire à celle obtenue avec l'utilisation de NO, et permet souvent des réajustements de la $\mathrm{FiO}_{2}$, de la PEEP et des paramètres du respirateur. L'amélioration de l'oxygénation survient rapidement (minutes) après le positionnement, bien que soient décrits des cas de réponse plus tardive. L'amélioration de l'oxygénation peut être amoindrie lorsque la position dorsale est reprise, bien que plusieurs études rapportent un effet bénéfique prolongé. Des épisodes répétés de décubitus ventral peuvent avoir des effets bénéfiques cumulatifs. La durée optimale du décubitus ventral est inconnue; variant de quelques heures à quelques jours, la durée doit être titrée à la réponse individuelle. Des arrêts du décubitus dorsal sont nécessaires pour les soins infirmiers, l'évaluation médicale ainsi que la réalisation de procédures médicales. La plupart des études rapportent peu de complications, les plus fréquentes étant des lésions mineures cutanées ou muqueuses, des oedèmes dépendants, et le retrait accidentel des voies vasculaires ou du tube endotrachéal. La plupart des patients tolèrent le changement de position sans grande modification hémodynamique. Les contre-indications à la position ventrale peuvent être une PIC augmentée, des fractures instables de la colonne ou du bassin et des pathologies intra-abdominales.

Pourquoi le décubitus ventral favorise-t-il l'oxygénation? En décubitus dorsal, il existe un gradient vertical de pression pleurale prononcé qui favorise la fermeture des voies aériennes dans des zones dépendantes, oedématiées. La gravité influence encore les pressions pleurales en décubitus ventral, mais de façon modifiée par les positions différentes du coeur, de la cage thoracique, du diaphragme, de l'abdomen et des structures médiastinales. Il en résulte une distribution plus uniforme des pressions pleurales, ce qui permet une distribution plus homogène de la ventilation. ${ }^{28}$ Étant donné le peu d'influence de la position ventrale sur la perfusion, la ventilation améliorée des segments dorsaux se traduit par de meilleurs ratios $\mathrm{V} / \mathrm{Q}$ et donc une diminution du shunt. Si les lésions pulmonaires sont diminuées par la réduction des volumes courants et par la prévention de l'ouverture-fermeture cyclique des alvéoles, alors la position ventrale ajoute à la prévention des lésions pulmonaires. Ainsi, des études animales montrent que le décubitus ventral, comparé au décubitus dorsal, prévient les lésions pulmonaires induites par l'hyperin- flation de poumons normaux ${ }^{29}$ de même qu'il diminue le degré d'anomalies histologiques dans un modèle animal de lésion pulmonaire aiguë. ${ }^{30}$ L'amélioration du drainage des sécrétions des zones pulmonaires dépendantes contribue possiblement aussi à l'amélioration de l'oxygénation.

Suite aux séries rapportées, de même qu'aux cas isolés, montrant une amélioration de l'oxygénation, la position ventrale est maintenant fréquemment utilisée. Une série de cas récente ${ }^{27}$ a montré une mortalité améliorée (lorsque comparée avec celle prédite par le score d'Apache), mais il n'existe pas encore d'études prospectives, randomisées démontrant une diminution de la morbidité et de la mortalité. Il n'existe pas de lignes directrices pour déterminer quand un patient peut bénéficier de la position ventrale; la décision est habituellement basée sur des critères d'oxygénation. S'il s'avère que le décubitus ventral est "protecteur", il pourrait alors être utilisé précocement ou même de façon "prophylactique" chez les patients à haut risque de SRDA.

Il existe donc plusieurs raisons pour considérer le décubitus ventral comme mesure de traitement primaire : en effet, c'est une méthode efficace, qui peut prévenir les LPIV, facile à exécuter, sécuritaire, comportant peu de contre-indications, pouvant être réalisée à peu près partout et ce à peu de frais.

\section{Ventilation non-invasive}

Le terme de ventilation non-invasive (VNI) s'applique à des techniques ne nécessitant pas de tube endotrachéal. Ce type de ventilation comporte de nombreux avantages : il évite les complications associées à l'intubation (incluant les pneumonies nosocomiales), nécessite moins de sédatifs et permet la conservation de la parole, de la déglutition ainsi que des réflexes protecteurs des voies aériennes. C'est un mode de ventilation existant depuis déjà plusieurs décades, initialement sous la forme de ventilation à pression négative (poumon d'acier) et plus récemment sous forme de masque à pression positive. Traditionnellement, cette forme de ventilation a été utilisée dans certaines conditions respiratoires chroniques telles que l'apnée du sommeil, la faiblesse neuromusculaire et les MPOC. Récemment cependant, la ventilation non-invasive a reçu beaucoup d'attention dans le traitement de l'insuffisance respiratoire aiguë. Bien que plusieurs modes de ventilation ont été efficaces par masque, la plupart des travaux portent sur le CPAP avec pression de support (PS). La pression de support permet au patient un certain contrôle quant aux temps inspiratoire et expiratoire tout en compensant pour les fuites. Le CPAP représente une pression positive continue alors qu'une pression positive inter- 
mittente, associée ou non au CPAP, est appelée ventilation non-invasive à pression positive (VNIPP).

La plupart des études ont évalué l'utilité de la ventilation non-invasive dans les cas d'insuffisance respiratoire aiguë chez des patients présentant une exacerbation de MPOC. Ces patients ont une fermeture prématurée des voies aériennes et développent une hyperinflation dynamique et une PEEP intrinsèque (PEEPi). Afin que le débit inspiratoire débute, les muscles inspiratoires doivent générer suffisamment de pression négative pour vaincre la PEEPi. Le CPAP par masque contrecarre le travail inspiratoire augmenté créé par la PEEPi, donc diminue le travail respiratoire global. La VNIPP augmente la ventilation minute, diminue le travail inspiratoire et améliore les échanges gazeux. La combinaison de CPAP et de VNIPP est supérieure à chacun des modes pris séparément. ${ }^{31}$ Plusieurs études prospectives randomisées ont montré des améliorations pour les points suivants : diminution des intubations trachéales, séjours hospitaliers plus courts et diminution de la mortalité. ${ }^{32-34} \mathrm{Il}$ existe cependant de nombreuses critiques; un choix très sélectif des patients certains patients contrôles décédés sans être intubés et un choix varié de techniques utilisées pour réaliser la VNIPP. Une métaanalyse récente a montré que l'ajout de VNIPP au traitement standard des patients souffrant de MPOC et ayant un épisode de décompensation aiguë diminuait la chance d'être intubé et entraînait une diminution de la mortalité ${ }^{35}$ Étant donné le manque de données, une telle affirmation ne peut être faite pour les cas d'insuffisance respiratoire aiguë chez les patients autres que ceux souffrant de MPOC. Des études noncontrôlées ont suggéré un bénéfice chez des patients présentant des exacerbations de leur asthme mais d'autres études seront nécessaires. D'autres études ont montré les bénéfices de la VNIPP quant à l'amélioration des échanges gazeux, de l'hémodynamique et des paramètres respiratoires de patients présentant un œdème pulmonaire cardiogénique, possiblement par une réduction de la pré-charge et de la post-charge. La VNIPP est actuellement le mode thérapeutique initial des patients atteints de fibrose kystique nécessitant un support ventilatoire en attendant une greffe pulmonaire ${ }^{36}$ Ce mode de ventilation a été utilisé avec succès dans les cas d'insuffisance respiratoire secondaire à l'atélectasie postopératoire.

La ventilation non-invasive peut être administrée par un ventilateur standard ou par un appareil spécialisé produisant des pressions inspiratoires et expiratoires. Les patients se doivent d'être alertes et coopératifs (exception faite de la narcose au $\mathrm{CO}_{2}$ ), capables de protéger leurs voies aériennes, stables hémodynamiquement et ayant une anatomie adéquate pour le masque. Un masque nasal ou un masque couvrant le nez et la bouche (full mask) peuvent être utilisés. La respiration buccale peut diminuer l'efficacité du masque nasal. Cependant, les masques nasaux sont moins claustrophobiants, permettent d'expectorer et de manger et boire sans devoir retirer le masque. Les complications sont rares; ce sont la nécrose cutanée, la distension gastrique, l'irritation oculaire et l'inconfort dû au masque. Pour plus de détails quant à la façon d'installer la ventilation noninvasive, pour des conseils pratiques et pour les soins impliqués, le lecteur peut consulter deux excellents articles. ${ }^{36,37}$

\section{Conclusion}

Bien qu'une quantité considérable de données expérimentales existent, les études cliniques préliminaires de la ventilation à pression et volumes limités n'ont pu établir son rôle et les bénéfices chez les patients avec lésions pulmonaires aiguës. De plus, il n'existe aucune étude contrôlée prouvant qu'un mode de ventilation mécanique est supérieur à un autre chez les patients avec SDRA. Le décubitus ventral devrait être considéré précocement dans les cas de SDRA, non seulement pour le traitement de l'hypoxie mais aussi pour ses effets protecteurs quant aux lésions pulmonaires induites par la ventilation. L'insufflation trachéale de gaz semble prometteuse dans les cas problématiques d'hypercarbie associée à la ventilation limitant la pression et le volume. Pour les patients appropriés, les complications associées à l'intubation endotrachéale peuvent être évitées par l'utilisation de VNIPP. La VNIPP s'est trouvé un rôle important dans le traitement de l'insuffisance respiratoire aiguë chez les patients porteurs de MPOC, et semble avoir certaines avenues prometteuses dans le traitement d'autres causes d'insuffisance respiratoire aiguë.

\section{Références}

(Voir page Rl53) 